\title{
Determining Factors Of Audit Delay Of Large Trading Companies On The Indonesia Stock Exchange
}

\author{
Astuti $^{1 *}$, Supitriyani ${ }^{2}$, Lenny Dermawan Sembiring ${ }^{3}$ \\ 1,2,3 Lecturer of Sekolah Tinggi Ilmu Ekonomi Sultan Agung \\ Sumatera Utara Indonesia, Indonesia. \\ ${ }^{*}$ Corresponding Author: \\ Email: azztuty91@gmail.com
}

\begin{abstract}
.
Financial statements delivered in a timely manner are useful in analyzing and making decisions in the economic field that can contribute to national economic growth. The timeliness of a financial statements on the results of the audit report can also affect the value of the financial statements. This research aims to find out and analyze the effect of leverage, company size and company age on audit delay. The conduct of the research was conducted on twenty Large Trading Companies during the period 20152019 which totaled 100 data. The data analysis techniques used in this research are descriptive statistical analysis, classical assumption test, multiple linear regression analysis, and hypothesis testing. The results showed that partially leverage had a positive and insignificant effect on audit delay, the company size had a negative and insignificant effect on audit delay, while the company age had a negative and significant effect on audit delay.
\end{abstract}

Keywords: Audit Delay, Company Age, Company Size, Leverage.

\section{INTRODUCTION}

Each company listed on the Indonesia Stock Exchange is required to submit financial statements that have been prepared in accordance with Financial Accounting Standards and have been audited by public accountants registered with the Capital Market Supervisory Agency. The fulfillment of standards by auditors not only has an impact on the length of reporting of audit results but also has an impact on the quality of the audit. The timeliness of a financial statement on the results of the audit report can affect the value of the financial statements and is also useful in analyzing and making decisions in the economic field that can contribute to national economic growth [1]. One of the company's constraints in publishing financial statements to the public and to the Capital Market Supervisory Agency is the timeliness of the auditor in completing his audit report [2].

The time span of completion of the audit report on the annual financial statements, measured based on the length of days needed to obtain the independent auditor's financial statements on the audit of the company's financial statements from the closing date of the company's book, which is december 31 to the date stated in the independent auditor's report is called audit delay. Audit delays that exceed the deadline for the provisions of the Financial Services Authority (OJK) certainly result in delays 
in the publication of financial statements. OJK requires public companies that have been listed on the Indonesia Stock Exchange to submit annual financial statements no later than 4 (four) months after the financial year ends or 120 days after the book closes. This is in accordance with OJK Regulation No. 29/POJK.04/2016 on Annual Report of Issuers or Public Companies [3]. Companies that are late to submit financial statements will be subject to written or unwritten sanctions [4].Based on the Indonesia Stock Exchange Announcement dated June 10, 2020 concerning the Submission of Audited Financial Statements Ended December 31, 2019 there are sixty-four (64) companies that have not submitted financial statements in a timely manner with percentages in figure 1 [5].

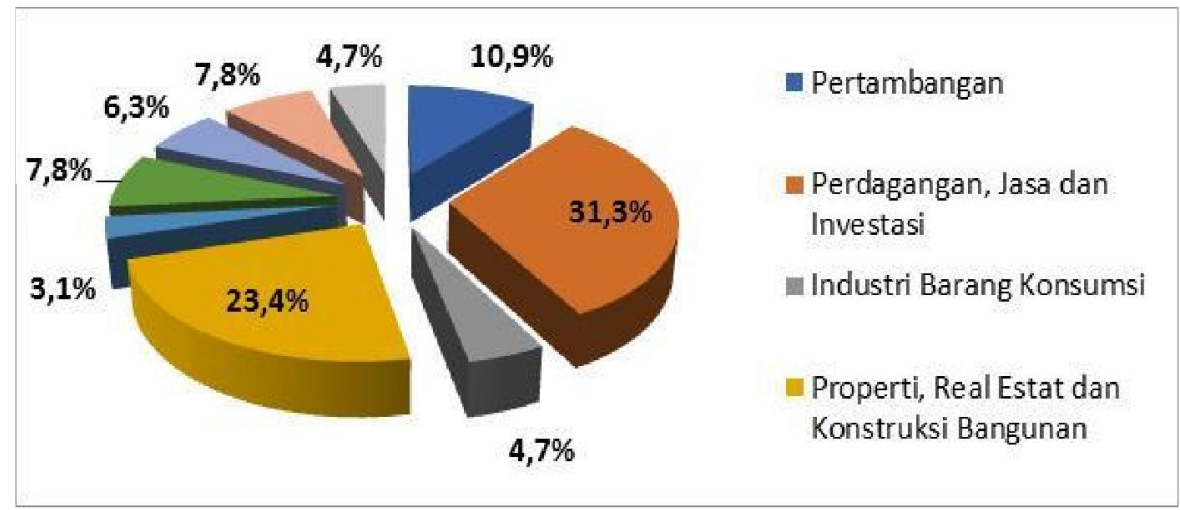

Source: [5]

Fig 1. Percentage of Companies That Submitted Audited Financial Statements Ended December 31, 2019

Quoted from the IDX Announcement, there are 20 Trading Companies that are late to submit financial statements for the period of December 31, 2019, seven of which are Large Trading Companies namely PT Asia Sejahtera Mina, Tbk, PT Exploitation Energi Indonesia, Tbk, PT Evergreen Invesco, Tbk, PT Intraco Penta, Tbk, PT Modern International, Tbk, PT Tira Austenite, Tbk, and PT Triwira Insanlestari, Tbk.There are several factors that can affect the timeliness of financial statements, including leverage, the scale or company size and the company age. Leverage is the ratio used to measure a company's ability to meet its liability. The high leverage ratio reflects the company's high financial risk [4]. The small amount of leverage can be measured by Debt Ratio, Debt to Equity Ratio, Time Interest Earned Ratio and Long Term Debt to Equity Ratio. Debt Ratio is used to measure the proportion of funds sourced from debt to finance the assets of a calculated company by comparing total debt with total assets. Debt to Equity Ratio is used to measure the proportion of funds sourced from a company's equity to be used as collateral for calculated debt by comparing total debt with total equity. Time Interest Earned Ratio is used to measure a company's ability to pay fixed expenses in the form of interest using EBIT (Earning Before Interest and Taxes) which is calculated by comparing EBIT with 
interest. The Long Term Debt to Equity Ratio is used to measure the small use of longterm debt compared to a company's own capital [6]. The leverage in this research was measured using the Debt Ratio (DR), with the formula:

$$
\text { Debt Ratio }(D R)=\frac{\text { Total Liability }}{\text { Total Ass et }}
$$

Research [7] states that a high proportion of debt causes companies to get a little problem where the company inevitably has to confirm the acquisition of debt that the company has to the relevant parties. The greater the company's debt, it will extend the process that must be carried out by the relevant parties and have an impact on the preparation of audit reports that are automatically hampered and have an impact on long audit delays. Based on the description above, the hypothesis can be formulated as follows.

\section{H1: Leverage positively affects audit delay}

The size of a company can be interpreted as a comparison of the size or small business of a company or organization [8]. The company size is usually seen from the total assets, sales, and market capitalization. Of the three variables above, the company size through total assets tends to be more stable than through sales. This is because sales tend to fluctuate more each year than total assets. While the market capitalization value is the value of the company calculated through the results of times between the number of outstanding shares and the market value of shares per share [9]. In this research the company size was measured by total assets, with the formula:

$$
\text { Company Size }=\operatorname{Ln}(\text { Total Asset })
$$

Research [10] states that large companies will complete the audit process faster than small companies, this is due to several factors, namely large-scale company management tends to be given incentives to reduce audit delays because the company is closely monitored by investors, capital supervisors, and the government. Companies with large total assets and strong internal control are good news for the company. This is related to the signal theory, that the company will tend to report its financial statements faster if the company has good news. Based on the description above, the hypothesis can be formulated as follows.

$\mathrm{H} 2$ : The company size negatively affects audit delays

The company age is the length of time the company runs the business, calculated from the date of the company's establishment until the year of book closing [11]. The company age in this research is measured by the length of time from the establishment of the company to the close of the company's book.

Company Age $=$ Year of book closing - Year of the company's establishment 
Research [12] states that it conforms to the company's signaling theory where a short audit delay is experienced by a long-established company compared to a newly established company. Companies that have been doing operations for a long time are considered to be more capable in carrying out all their obligations compared to companies that have not long operated. The company's ability to prepare everything needed in the audit process can result in the time needed when auditing will be less because the company has experience related to it. Based on the description above, the hypothesis can be formulated as follows.

H3: The company age negatively affects audit delay

Previous research related to audit delays included [13] examining the Effect of Company Size, Audit Opinion, Profitability, Operation Complexity, and Leverage On Audit Delay with partial results of audit opinion and profitability having a significant negative effect on audit delay, as well as operating complexity having a significant positive effect on audit delay.

While the variables of company size and leverage do not have a significant influence on audit delays. Other studies [14] examined the influence of profitability, solvency and the size of companies on audit report lag with KAP's reputation as a moderating variable with profitability results not having a significant negative effect on audit report lag. Solvency has a significant negative effect on audit report lag, the company size positively affects audit report lag and kap reputation does not strengthen the influence of profitability, solvency and company size on audit report lag.In addition, there is also research related to audit delay, which is conducted by [15] with the title Of Influence of Company Size, Solvency, Profitability, Audit Opinion and Company age Against Audit Delay On Customer Goods Company with partial results showing that the company size, solvency, profitability and company age does not significantly affect audit delay while audit opinion has a positive and significant effect on audit delay on the company an industry of consumer goods sector contained on the Indonesia Stock Exchange (IDX). This research was conducted to find out and analyze the influence of leverage, company size and company age on audit delays on Large Trading Companies listed on the Indonesia Stock Exchange with a research period of 2015 to 2019, where previously there was still little research that examined audit delays in this Company with the period 2015 to 2019. The research used the latest data from 2015 to 2019 for 5 years. The time span of the research and the year of this research is used to distinguish with previous research so that this research is expected to be able to produce more significant research results.

\section{METHODS}

This research uses literature research design with a quantitative approach. Quantitative approach can be interpreted as a research method based on the philosophy of positivism, used to examine a particular population or sample, data collection using research instruments, quantitative / statistical data analysis, with the aim of describing 
and testing established hypotheses [16].The population in this research is all Large Trading Companies registered with the IDX as of December 31, 2019, which is 47 population. Sampling technique is purposive sampling, which is sampling based on certain criteria, among others, companies that publish their financial statements in full and never experience a loss of 3 years during the research period. Based on the selection obtained 20 Companies that will be sampled, among others with the following issuer codes: AKRA, APII, CLPI, DPUM, DSSA, EPMT, FISH, INTD, JKON, KOBX, LTLS, MICE, MPMX, SDPC, TGKA, TIRA, TURI, UNTR, WAPO and WICO.

The data analysis techniques used in this research are:

\section{Descriptive Statistical Analysis}

Descriptive statistical analysis is used to provide an overview of leverage, company size, company age and audit delay as seen from minimum values, maximum values, average values, and standard deviations.

\section{Classical Assumption Test}

Classical assumption tests are performed to assess whether in the Ordinary Least Square (OLS) linear regression model there are problems with classical assumptions. The tests used are normality, multicollinearity, autocorrectual and heteroskedasticity tests.

\section{Multiple Linear Regression Analysis}

Multiple linear regression analysis is performed to find out whether independent variables include leverage, company size and company age to affect dependent variables, namely audit delay [16]. The equations used are:

Audit Delay $=\alpha+\beta 1$ Lev $+\beta 2$ Size $+\beta 3$ Age

\section{Hypothesis Testing}

Determination Coefficient Test (R Square) The coefficient of determination ( $R$ Square) test is used to measure how much leverage, company size and age in explaining audit delays [17].

\section{Simultaneous Significance Test (Test F)}

Simultaneous significance tests ( $F$ tests) are performed to show whether leverage, company size and company age simultaneously or together significantly affect audit delays [17]. By using alpha of 5\% then the testing criteria is if the sig value $<\alpha$, then simultaneously leverage, company size and company age have a significant effect on audit delay, and apply the opposite.

\section{Individual Significance Test (Test t)}

Individual significance tests ( $\mathrm{t}$ tests) are performed to show whether leverage, company size and company age partially or individually affect audit delays significantly [17]. Using alpha of $5 \%$ or 0.05 then the testing criteria is if the sig value $<\alpha$, then partially leverage, company size and company age significantly affect audit delay, and apply the opposite. 


\section{RESULT AND DISCUSSION \\ Descriptive Statistical Analysis}

The results of descriptive statistical analysis in this research are shown in Table 1. Table 1 presents the results of descriptive statistical analysis of the variables analyzed, namely Leverage with DR proxy has a minimum value of 0.143 , a maximum value of 0.948 , an average value (mean) of 0.48037 , and a standard deviation of 0.182102. Furthermore, the Company size with the proxy Ln (Total Assets) has a minimum value of 24,568 , a maximum value of 32,387 , a mean value of 28.40766 and a standard deviation of 1.847038 . Then, the Audit Delay variable has a minimum value of 49 , a maximum value of 154 , an average value (mean) of 80.37 , while a standard deviation value of 20,187 .

Table 1. Results of Descriptive Statistical Analysis

\begin{tabular}{lrrrrr}
\hline & $\mathrm{N}$ & Minimum & Maximum & \multicolumn{1}{c}{ Mean } & Std. Deviation \\
\hline DAR & 100 &, 143 &, 948 &, 48037 &, 182102 \\
LnTotalAset & 100 & 24,568 & 32,387 & 28,40766 & 1,847038 \\
Umur & 100 & 3 & 68 & 33,70 & 15,066 \\
AuditDelay & 100 & 49 & 154 & 80,37 & 20,187 \\
Valid N (listwise) & 100 & & & & \\
\hline
\end{tabular}

Source: Secondary data processed (2021).

\section{Classic Assumption Test}

\section{Normality Test}

The research used a normality test with the Kolmogorov-Smirnov method based on a significance level of $5 \%$ or 0.05 . If the test results show a significance level greater than 0.05 , then the research data is normal or otherwise [17]. Based on the results of the data process using SPSS version 21, the results of the KolmogorovSmirnov test in this research were shown in Table 2 with a significance value result on the Asymp value. Sig. (2-tailed) of 0.061 or greater than 0.05 , so the results prove that the research data is normal distribution.

Table 2. Normality Test Results with Kolmogorov-Smirnov Method

\begin{tabular}{llr}
\hline & & Unstandardized Residual \\
\hline $\mathrm{N}$ & & 100 \\
Normal Parameters ${ }^{\mathrm{a}, \mathrm{b}}$ & Mean &, 0000000 \\
& Std. Deviation & 19,19674086 \\
& Absolute &, 132 \\
Most Extreme Differences & Positive &, 132 \\
& Negative &,- 080 \\
Kolmogorov-Smirnov Z & & 1,321 \\
Asymp. Sig. (2-tailed) & &, 061 \\
\hline
\end{tabular}

Source: Secondary data processed (2021).

\section{Multicollinearity Test}

The research used multicollinearity tests based on Tolerance (TOL) and Variance Inflation Factor (VIF) values from each free variable. If the TOL value is greater than 0.1 and the VIF is smaller than 10 , then the model is declared to have no 
symptoms of multicollinearity [17]. Based on the results of data processing using SPSS version 21, the results of the multicollinearity test in this research shown in Table 3 with the results of TOL values of all free variables greater than 0.10 and VIF values smaller than 10 , so the results prove that there are no symptoms of multicollinearity in this research data.

Table 3. Multicollinearity Test Results Based on TOL and VIF values

\begin{tabular}{llcc}
\hline Model & \multicolumn{3}{c}{ Collinearity Statistics } \\
\cline { 3 - 4 } & (Constant) & \multicolumn{3}{c}{ Tolerance } \\
\hline \multirow{3}{*}{1} & DAR & 923 & 1,083 \\
& LnTotalAset & 992 & 1,018 \\
& Umur & 994 & 1,064 \\
\hline
\end{tabular}

Source: Secondary data processed (2021).

\section{Autocorrelation Test}

A proper regression model is a regression model that is free of autocorrelation. The research used an autocorrelation test with Durbin Watson's method, with criteria in Table 4.

Table 4. Autocorrelation Test Criteria

\begin{tabular}{|c|c|c|}
\hline Null hypothesis & Decision & Criteria \\
\hline There is no positive autocorrelation. & Reject & $0<\mathrm{d}<\mathrm{dl}$ \\
\hline There is no positive autocorrelation. & Without conclusion & $\mathrm{dl} \leq \mathrm{d} \leq \mathrm{du}$ \\
\hline There is no negative correlation. & Reject & $4-\mathrm{dl}<\mathrm{d}<4$ \\
\hline There is no negative correlation. & Without conclusion & $4-\mathrm{du} \leq \mathrm{d} \leq 4-\mathrm{dl}$ \\
\hline $\begin{array}{l}\text { There is no positive or negative } \\
\text { autocorrelation. }\end{array}$ & Not rejected & $\mathrm{du}<\mathrm{d}<4-\mathrm{du}$ \\
\hline
\end{tabular}

Source: [17]

Based on the results of data processing using SPSS version 21, the results of the autocorrelation test in this research were shown in Table 5 with a durbin watson score of 1.703. The values $\mathrm{dl}$ and du obtained from Durbin Watson's table are $\mathrm{dl}$ values of 1.5922 and du values of 1.7582. Durbin Watson's values were between $\mathrm{dl}$ and du, $\mathrm{dl}$ $<\mathrm{d}<\mathrm{du}$ or $1.5922<1.703<1.7582$, so the results showed that the data in the research did not have a positive autocorrelation with the decision without conclusion.

Table 5. Autocorrelation Test Results with Durbin Watson Method

\begin{tabular}{lll}
\hline Model & Durbin-Watson & \\
\hline 1 & & 1,703 \\
\hline
\end{tabular}

Source: Secondary data processed (2021).

\section{Heteroscedasticity Test}

In this research, the heteroscedasticity test was conducted using graph analysis. If the scatterplot spreads randomly both above and below the number 0 on the $\mathrm{Y}$ axis, it can be interpreted that there is no problem of heteroscedasticity in the regression model formed. The right regression model is a regression model that is free from the problem of heteroscedasticity [17]. Based on the results of data processing using SPSS version 21, the results of the heteroscedasticity test in this research shown in Figure 2 
with scatterplot results spread randomly both above and below the number 0 on the $\mathrm{Y}$ axis, it can be interpreted that there is no problem of heteroscedasticity in the regression model formed.

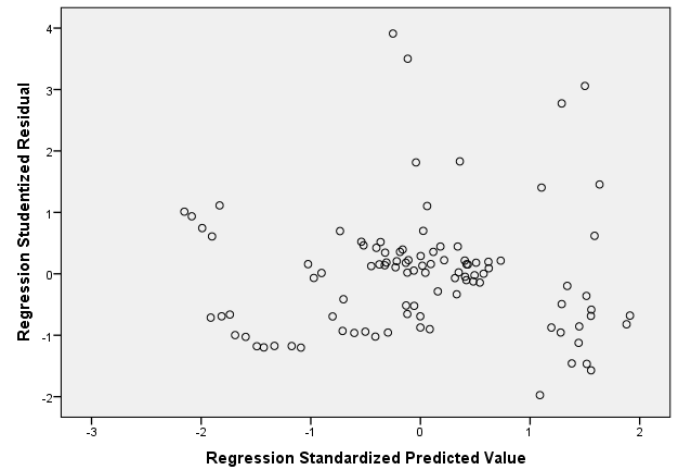

Source: Secondary data processed (2021).

Fig. 2. Heteroscedasticity Test Results with Graph Methods

\section{Multiple Linear Regression Analysis}

The results of the multiple linear regression analysis in this research were shown in Table 6, with the results showing that leverage had a positive effect on audit delay while the company size and the company age negatively affected audit delay. The results of multiple linear regression equations are:

$$
\text { Audit Delay }=139.749+5.794 \text { Lev }-1.753 \text { Size }-0.367 \text { Age }
$$

The multiple linear regression equations above can be interpreted as follows:

1. The constant value of 139.749 which can be interpreted if the leverage, company size and the company age is assumed to be equal to 0 (zero), then the audit delay is worth the constant which is 139.749 .

2. $\beta 1=5,794$ which means that each increase of 1 unit of leverage will cause an increase in audit delay of 5,794 units assuming other free variables are considered constant.

3. $\beta 2=-1,753$ means that any increase of 1 unit of company size will cause audit delays to decrease by 1,753 units assuming other free variables are considered constant.

4. $\beta 3=-0.367$ means that any increase of 1 unit of company age will cause audit delay to decrease by 0.367 units assuming other free variables are considered constant.

Table 6. Multiple Linear Regression Test Results

\begin{tabular}{rlrrr}
\hline Model & \multicolumn{2}{c}{ Unstandardized Coefficients } & \multicolumn{2}{c}{$\begin{array}{c}\text { Standardized } \\
\text { Coefficients }\end{array}$} \\
\cline { 3 - 5 } & & \multicolumn{2}{c}{ B } & \multicolumn{2}{c}{ Std. Error } & \multicolumn{1}{c}{ Beta } \\
\hline \multirow{4}{*}{1} & (Constant) & 139,749 & 30,445 & \\
& Lev & 5,794 & 11,199 &, 052 \\
& Size & $-1,753$ & 1,071 &,- 160 \\
& Age &,- 367 &, 134 &,- 274 \\
\hline
\end{tabular}

Source: Secondary data processed (2021). 


\section{Hypothesis Testing}

\section{The Determination Coefficient (R Square)}

The determination coefficient (R Square) test is used to measure how much leverage, profitability, company size and KAP's reputation in explaining audit delays [17]. Based on the results of the data in Table 7 obtained the coefficient of determination ( $\mathrm{R}$ Square) of 0.106 . The results can be interpreted that leverage, profitability, company size and KAP's reputation were able to explain the audit delay of $10.6 \%$, while the remaining $89.4 \%$ was explained by other factors not studied in the research.

Table 7. Determination Coefficient Test Results (R Square)

\begin{tabular}{llrrr}
\hline Model & R & R Square & \multicolumn{1}{c}{ Adjusted R Square } & \multicolumn{1}{c}{ Std. Error of the Estimate } \\
\hline 1 &, $309^{\mathrm{a}}$ &, 096 &, 067 & 19,494 \\
\hline
\end{tabular}

Source: Secondary data processed (2021).

\section{Simultaneous Significance Test (F Test)}

Based on the results of the data in Table 8 obtained a significance value smaller than 0.05 which is 0.021 . Thus it can be interpreted that simultaneously leverage, company size and company age have a significant effect on audit delay.

Table 8. Simultaneous Significance Test Results (F Test)

\begin{tabular}{llrrrrr}
\hline Model & & Sum of Squares & df & Mean Square & F & \multicolumn{1}{c}{ Sig. } \\
\hline \multirow{1}{*}{1} & Regression & 3860,339 & 3 & 1286,780 & 3,386 &, $021^{\text {b }}$ \\
& Residual & 36482,971 & 96 & 380,031 & & \\
& Total & 40343,310 & 99 & & & \\
\hline
\end{tabular}

Source: Secondary data processed (2021).

\section{Individual Significance Test (t Test)}

Based on the results of the data in Table 9 obtained a value of significance for each independent variable, namely:

1. The leverage variable has a regression coefficient value $(\beta 1)$ of 5,794 which means that leverage has a positive effect on audit delay. Where the value of the significance of the test $t$ on the leverage variable is 0.606 where the value is greater than the value of the $\alpha$ which is 0.05 . The results showed that leverage had a positive and insignificant effect on audit delays, so the first hypothesis was accepted. The results of this research indicate that if the leverage ratio is higher, it will have a direct impact on the risk of greater loss, making auditors more careful in conducting audits of the company's financial statements. This situation makes the management tend to take the decision to delay the submission of financial statements resulting in longer audit delays. The results of this research are in line with previous research conducted by [7], which stated that leverage positively affects audit delay, meaning that the more debt received by the company, the longer the audit delay.

2. The company size variable has a regression coefficient ( $\beta 2)$ value of $-1,753$ which means that the company size negatively affects the audit delay. Where the value of the significance of the test $t$ on the company size variable is 0.105 where the value is 
greater than the value of the $\alpha$ which is 0.05 . The results showed that the company size had a negative and insignificant effect on audit delays. Thus the second hypothesis is accepted. Based on these results, showing that large companies will complete the audit process faster than small companies, this is due to several factors, namely large-scale company management tends to be given incentives to reduce audit delays because the company is closely monitored by investors, capital supervisors, and the government. Companies with large sales and strong internal control are good news for the company. This is related to the signal theory, that the company will tend to report its financial statements faster if the company has good news. The results of this research are in line with previous research conducted by [18], which stated that the company size has negative implications on audit delays, meaning that large companies will be faster in completing financial statements so that the audit delay range will be shorter. Large companies tend to have more and more sophisticated information systems, resources, and have accounting staff so that they will be able to present financial statements in a shorter time.

3. The company's age variable has a regression coefficient $(\beta 3)$ value of -0.367 which means that the company age negatively affects audit delay. Where the test significance value $t$ on the company size variable is 0.007 where the value is smaller than the value of the $\alpha$ which is 0.05 . The results showed that the company size had a negative and significant effect on audit delays. Thus the third hypothesis is accepted. Based on these results, it shows that long-established companies tend to experience shorter audit delays compared to newly established companies. Companies that have been doing operations for a long time are considered to be more capable in carrying out all their obligations compared to companies that have not long operated. The results of this research were not in line with the research conducted by [15] with partial results of the company's lifespan having no significant effect on audit delays.

Table 9. Individual Significance Test Results (t Test)

\begin{tabular}{rlrrrrr}
\hline Model & & \multicolumn{2}{c}{ Unstandardized Coefficients } & $\begin{array}{c}\text { Standardized } \\
\text { Coefficients } \\
\text { Beta }\end{array}$ & $\mathrm{t}$ & Sig. \\
\hline \multirow{4}{*}{1} & B & Std. Error & 30,445 & & 4,590 &, 000 \\
& (Constant) & 139,749 & 30,417 &, 606 \\
& Lev & 5,794 & 11,199 &, 052 &, 517 \\
& Size & $-1,753$ & 1,071 &,- 160 & $-1,637$ &, 105 \\
& Age &,- 367 &, 134 &,- 274 & $-2,735$ &, 007 \\
\hline
\end{tabular}

Source: Secondary data processed (2021).

\section{CONCLUSION}

Based on the description of the results of research and discussion, the results of this research concluded that simultaneously leverage, company size and company age have a significant effect on audit delay. While partial leverage has a positive and insignificant effect on audit delay, the company size has a negative and insignificant effect on audit delay while the company age has a negative and significant effect on 
audit delay.From the results of this research, it is advisable for companies to always pay attention to punctuality in the delivery of financial statements. If the financial statements are submitted on time, i.e. no more than 4 (four) months or 120 days from the expiration of the book closing date then the audit delay can be reduced. The company is also expected to pay more attention to the factors that affect audit delay, because audit delay is one of the important aspects for a company as a consideration in decision making so that interested parties do not wait too long.

Furthermore, related to the number of companies that are late and do not comply with regulations in the submission of financial statements to the public, so a firm stance from Bapepam-LK as an institution that oversees the capital market is needed. Improvements in regulations and sanctions need to be made so that each company is more disciplined in the delivery of financial statements so as not to harm various interested parties. With respect to the limited time and effort of the author, the research is still unable to reveal all the variables that can affect the audit delay, so that the researcher is further advised to use other variables that can affect the audit delay. Future research may use other analytical methods or techniques to deepen the analysis, as well as compare it with the methods already used in this research. In addition, future research is also expected to extend the research period and conduct testing in other groups of companies in order to obtain better and accurate results.

\section{ACKNOWLEDGMENTS}

The authors are grateful to the research funder, the support of the facility, or the help of manuscript reviews. We also thank the Ministry of Ristekdikti who had financed this research from start to finish and to LPPM's Sekolah Tinggi Ilmu Ekonomi Sultan Agung who had facilitated the team in conducting research. This research is the result of a Beginner Lecturer Research grant that is fully financed by the Ministry of Ristekdikti.

\section{REFERENCES}

[1] F. Rahardi and E. Diah, "Faktor-Faktor Yang Mempengaruhi Audit Delay Dengan Reputasi Kap Sebagai Variabel Pemoderasi (Studi Pada Perusahaan Lq 45 Yang Terdaftar Di Bursa Efek Indonesia Pada Tahun 2015-2019)," J. Akunt. Keuang. Unja, vol. 6, no. 1, pp. 18-33, 2021, [Online]. Available: https://onlinejournal.unja.ac.id/jaku/article/view/13299/11206.

[2] D. M. T. Putri, G. Pagalung, and G. T. Pontoh, "Pengaruh Ukuran Perusahaan, Leverage, Profitabilitas dan Ukuran KAP terhadap Audit Delay," Akrual J. Bisnis dan Akunt. Kontemporer, vol. 14, no. 2, pp. 163-172, 2021, doi: https://doi.org/10.26487/akrual.v14i2.14808.

[3] O. J. K. R. Indonesia, "Peraturan Otoritas Jasa Keuangan Republik Indonesia Nomor 29/POJK.04/2016 Tentang Laporan Tahunan Emiten atau Perusahaan Publik," 2016. doi: https://www.ojk.go.id/id/kanal/pasar-modal/regulasi/peraturanojk/Documents/Pages/POJK-Laporan-Tahunan-Emiten-Perusahaan-Publik/POJK- 
Laporan-Tahunan.pdf.

[4] N. M. M. Lapinayanti and I. K. Budiartha, "Pengaruh Profitabilitas dan Leverage Pada Audit Delay dengan Ukuran Perusahan Sebagai Pemoderasi," E-Jurnal Akunt., vol. 23, p. 1066, 2018, doi: 10.24843/EJA.2018.v23.i02.p10.

[5] B. E. Indonesia, "Pengumuman Penyampaian Laporan Keuangan Auditan yang Berakhir Per 31 Desember 2019," 2020. [Online]. Available: http://www.idx.co.id/Portals/0/StaticData/NewsAndAnnouncement/ANNOUNCEMEN TSTOCK/From_EREP/201504/e59da9a281_9b34f295a6.pdf.

[6] S. Aisyah et al., Manajemen Keuangan. Medan: Yayasan Kita Menulis, 2020.

[7] P. F. Siahaan and A. Andayani, "Pengaruh Profitabilitas, Leverage, Kualitas Kap Dan Opini Auditor Terhadap Audit Delay," J. Ilmu dan Ris. Akunt., vol. 10, no. 5, 2021,[Online].Available:

http://jurnalmahasiswa.stiesia.ac.id/index.php/jira/article/view/3997/4008.

[8] Hery, Kajian Riset Akuntansi. Jakarta: Grasindo, 2017.

[9] Anita and A. D. Cahyati, "Pengaruh Profitabilitas, Solvabilitas, dan Opini Auditor terhadap Audit Delay dengan Ukuran Perusahaan sebagai Variabel Pemoderasi," J. Penelit. Teor. Terap. Akunt., vol. 4, no. 2, pp. 106-127, 2019, doi: https://doi.org/10.51289/peta.v4i2.408.

[10] R. Elvienne and P. Apriwenni, "Pengaruh Profitabilitas, Solvabilitas, Dan Ukuran Perusahaan Terhadap Audit Delay Dengan Reputasi KAP Sebagai Pemoderasi,” J. Akunt., vol. 8, no. 2, pp. 125-147, 2019, doi: 10.46806/ja.v8i2.616.

[11] A. C. Damanik, J. Nainggolan, Y. Simbolon, and E. N. Simorangkir, "Pengaruh Profitabilitas, Ukuran Perusahaan, Leverage, Umur Perusahaan Terhadap Audit Delay Pada Perusahaan Consumer Good Industry Yang Terdaftar Di Bei Tahun 2017-2019," J. Ilm. MEA (Manajemen, Ekon. Akuntansi), vol. 5, no. 2, pp. 947-962, 2021, doi: https://doi.org/10.31955/mea.vol5.iss2.pp947-962.

[12] D. D. Yanti, R. E. Zagoto, and W. A. Ginting, "Audit Delay serta Faktor Internal Perusahaan: Studi Kasus Perusahaan Trade, Service, and Investment," Own. Ris. dan J. Akunt., vol. 5, no. 2, pp. 483-491, 2021, doi: https://doi.org/10.33395/owner.v5i2.411.

[13] S. Ananda, W. A. Andriyanto, and R. Sari, "Pengaruh Ukuran Perusahaan, Opini Audit, Profitabilitas, Kompleksitas Operasi, dan Leverage Terhadap Audit Delay," in Prosiding BIEMA (Business Management, Economic, and Accounting National Seminar), 2021, vol. 2, [Online]. Available: https://conference.upnvj.ac.id/index.php/biema/article/view/1675/1134.

[14] R. Andiyanto, R. Andini, and P. D. P, "Pengaruh Profitabilitas, Solvabilitas, Dan Ukuran Perusahaan Terhadap Audit Report Lag Dengan Reputasi Kap Sebagai Variabel Moderating Pada Perusahaan Keuangan Yang Terdaftar Di Bursa Efek Indonesia Periode 2011-2015," J. Account. J. Ilm. Mhs. S1 Akunt. Univ. Pandanaran, vol. 3, no. 3, p. 16, 2017, [Online]. Available: https://jurnal.unpand.ac.id/index.php/AKS/article/view/807.

[15] A. P. Putri, L. Wati, J. Chriestien, and C. Wijaya, "Pengaruh Ukuran Perusahaan, Solvabilitas, Profitabilitas, Opini Audit Dan Umur Perusahaan Terhadap Audit Delay Pada Perusahaan Customer Goods,” J. Ilm. MEA (Manajemen, Ekon. Akuntansi), vol. 5, no. 2, pp. 480-497, 2021, doi: 
https://doi.org/10.31955/mea.vol5.iss2.pp480-497.

[16] Sugiyono, Metode Penelitian Kuantitatif Kualitatif dan R\&D. Bandung: CV Alfabeta, 2019.

[17] I. Ghozali, Aplikasi analisis multivariate dengan program SPSS. Semarang: Badan Penerbit Universitas Diponegoro, 2016.

[18] I. G. A. A. R. Prabasari and N. K. L. A. Merkusiwati, "Pengaruh Profitabilitas, Ukuran Perusahaan, Dan Komite Audit Pada Audit Delay Yang Dimoderasi Oleh Reputasi KAP,” E-Jurnal Akunt. Univ. Udayana, vol. 20, pp. 1704-1733, 2017, doi: 10.24843/EJA.2017.v20.i02.p30. 